\title{
Amaurotic and ophthalmoplegic presentation of Balint syndrome
}

自

Figure Posterior predominant white matter abnormalities on brain MRI

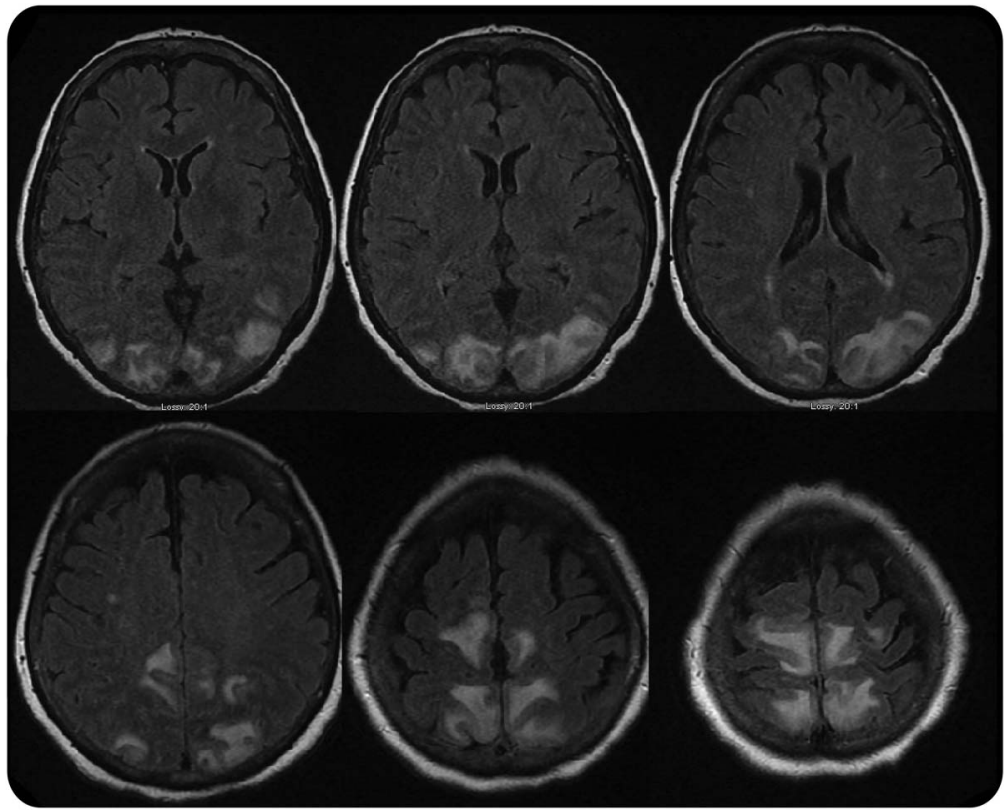

Axial fluid-attenuated inversion recovery brain MRI demonstrates patchy hyperintensities in the parietal and occipital subcortical regions bilaterally, typical of the vasogenic edema associated with the posterior reversible encephalopathy syndrome.

A 54-year-old woman developed acute hypertensive encephalopathy associated with acetaminophen-induced liver failure. Examination showed blindness with absence of horizontal and vertical volitional and reflex saccades (video on the Neurology ${ }^{\circledR}$ Web site at Neurology.org, first segment). MRI showed biparieto-occipital signal abnormalities consistent with the posterior reversible encephalopathy syndrome (PRES) (figure). Within 24 hours, visual acuity and eye movements improved, but the patient developed ocular apraxia (increased saccadic latency), optic ataxia (impaired visual navigation), and simultanagnosia (inability to recognize more than a single object): the Balint syndrome (video, second segment). This illustrates that a severe expression of oculomotor apraxia can mimic complete ophthalmoplegia ${ }^{1}$ and that Balint syndrome may occur at the onset ${ }^{2}$ and during recovery from PRES.

Alberto J. Espay, MD, MSc, FAAN, Scott R. Allen, MD

From the Department of Neurology, UC Neuroscience Institute, Movement Disorders Center, University of Cincinnati, OH.

Author contributions: Alberto J. Espay: drafting/revising the manuscript, study concept or design, analysis or interpretation of data, accepts responsibility for conduct of research and final approval, acquisition of data. Scott R. Allen: drafting/revising the manuscript, study concept or design, analysis or interpretation of data, accepts responsibility for conduct of research and final approval, acquisition of data.

Study funding: No targeted funding reported.

Disclosure: A. Espay is supported by the K23 career development award (NIMH, 1K23MH092735); has received grant support from CleveMed/Great Lakes Neurotechnologies, Davis Phinney Foundation, and Michael J. Fox Foundation; has received personal compensation as a consultant/scientific advisory board member for Solvay (now Abbvie), Chelsea Therapeutics, TEVA, Impax, Merz, Solstice Neurosciences, Eli Lilly, and USWorldMeds; and has received honoraria from Novartis, UCB, TEVA, the American Academy of Neurology, and the Movement Disorders Society. He serves as Associate Editor of Movement Disorders and Frontiers in Movement

Supplemental data at Neurology.org 
Disorders and on the editorial board of The European Neurological Journal. S. Allen reports no disclosures relevant to the manuscript. He is a PGY2 Neurology resident at the University of Cincinnati. Go to Neurology.org for full disclosures.

Correspondence to Dr. Espay: alberto.espay@uc.edu

1. Yee RD, Purvin VA. Acquired ocular motor apraxia after aortic surgery. Trans Am Ophthalmol Soc 2007;105:152-158; discussion 158-159.

2. Kumar S, Abhayambika A, Sundaram AN, Sharpe JA. Posterior reversible encephalopathy syndrome presenting as Balint syndrome. J Neuroophthalmol 2011;31:224-227.

\section{Mitigate Opioid Misuse in Your Practice}

100 people die from drug overdoses every day in the United States.* Learn how to mitigate opioid misuse in your practice with the AAN's NeuroPITM performance improvement module on Chronic Opioid Therapy.

- Helps address both the Performance in Practice (PIP) and Continuing Medical Education (CME) components of Maintenance of Certification (MOC), as mandated by the American Board of Psychiatry and Neurology (ABPN)

- Tackles the timely issue of chronic opioid therapy for non-cancer pain

- Offers measures to address strategies for mitigating opioid misuse

- Features educational resources, links to clinical tools, and patient education materials

Visit www.aan.com/view/neuropi today!

${ }^{*}$ CDC. Vital Signs: Overdoses of Prescription Opioid Pain Relievers-United States, 1999-2008. MMWR 2011;60:1-6

\section{Earn 20 CME Credits Toward MOC with New NeuroPI ${ }^{\text {SM }}$ Modules}

Choose from the latest lineup of quality modules to join the AAN's exclusive performance improvement programs designed to help you address both the Performance in Practice (PIP) and Continuing Medical Education (CME) components of Maintenance of Certification (MOC).

- NEW! Distal Symmetric Polyneuropathy (DSP) includes eight quality measures, addressing accurate and appropriate evaluation/monitoring of DSP and associated symptoms to guide treatment options, patient safety, and best practices to assist patients in managing their pain and improving quality of life

- Acute Stroke addresses six quality measures, including deep vein thrombosis prophylaxis (DVT) for ischemic stroke or intracranial hemorrhage, discharged on antiplatelet therapy, dysphagia screening, rehabilitation service considerations, and more

- Dementia includes $\mathbf{1 0}$ quality measures addressing underuse of effective services and patientcentered care strategies, and patient safety issues

Learn about all of the other available modules and purchase yours today:

www.an.com/view/neuropi 


\title{
Neurology
}

\author{
Amaurotic and ophthalmoplegic presentation of Balint syndrome \\ Alberto J. Espay and Scott R. Allen \\ Neurology 2014;82;1844-1845 \\ DOI 10.1212/WNL.0000000000000441
}

This information is current as of May 19, 2014

\section{Updated Information \& Services \\ Supplementary Material \\ References \\ Subspecialty Collections}

Permissions \& Licensing

Reprints including high resolution figures, can be found at: http://n.neurology.org/content/82/20/1844.full

Supplementary material can be found at: http://n.neurology.org/content/suppl/2014/05/18/82.20.1844.DC1

This article cites 2 articles, 0 of which you can access for free at: http://n.neurology.org/content/82/20/1844.full\#ref-list-1

This article, along with others on similar topics, appears in the following collection(s):

Clinical neurology examination

http://n.neurology.org/cgi/collection/clinical_neurology_examination Clinical neurology history

http://n.neurology.org/cgi/collection/clinical_neurology_history

Ocular motility

http://n.neurology.org/cgi/collection/ocular_motility

Information about reproducing this article in parts (figures,tables) or in its entirety can be found online at:

http://www.neurology.org/about/about_the_journal\#permissions

Information about ordering reprints can be found online:

http://n.neurology.org/subscribers/advertise

Neurology ${ }^{\circledR}$ is the official journal of the American Academy of Neurology. Published continuously since 1951, it is now a weekly with 48 issues per year. Copyright (O) 2014 American Academy of Neurology. All rights reserved. Print ISSN: 0028-3878. Online ISSN: 1526-632X.

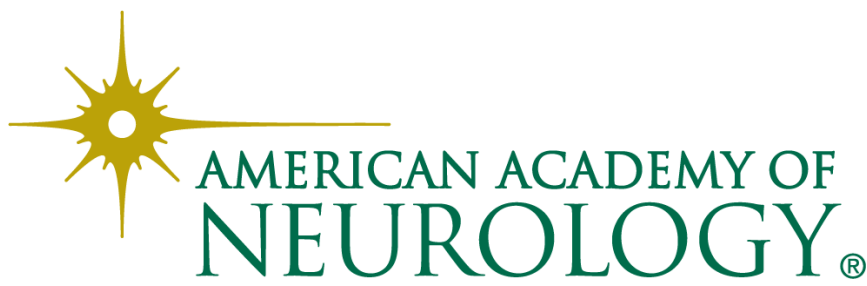

